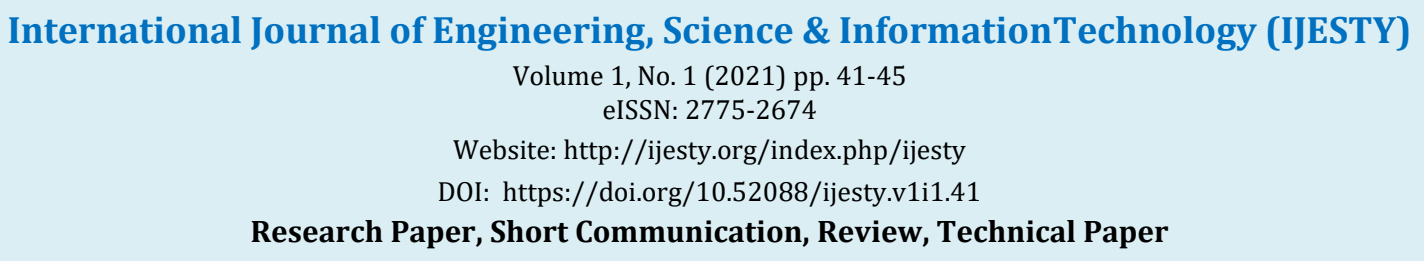

\title{
Estimated Flood Discharge in Downstream Krueng Meureubo of Pasi Pinang Section West Aceh Regency
}

\author{
Muhammad Ikhsan*, Rinaldy \\ Faculty of Engineering, Teuku Umar, Universitas Meulaboh, Aceh, Indonesia \\ *Corresponding authorE-mail: m.ikhsan@utu.ac.id
}

Manuscript received 1 Jan 2021; revised 10 Jan 2021; accepted 15 Jan 2021. Date of publication 20 Jan 2021

\begin{abstract}
The phenomenon of floods in Indonesia has become a routine thing that happens every year, almost all areas that are lowlands often flood when the rainy season arrives. Flooding is caused by high rainfall where the ability of the soil to absorb water decreases along with the rapid development of land that was once a rainwater catchment area, consequently surface runoff becomes high. Pasi Pinang Village can be categorized as a very flood prone village in Meureubo Subdistrict, due to the low condition of this village and directly borders the Meureubo river. Many adverse effects caused by floods and cause losses to the local community. The phenomenon of floods in Indonesia has become a routine thing that happens every year, almost all areas that are lowlands often flood when the rainy season arrives. Flooding is caused by high rainfall where the ability of the soil to absorb water decreases along with the rapid development of land that was once an area. In this case a study on flood discharge analysis needs to be done in order to reduce the incidence of flooding in the village of Pasi Pinang. The method used in this study is the Nakayasu HSS method, aim of this study is to determine the amount of flood discharge that occurred in the Krueng Meureubo River Basin in Pasi Pinang Village. Total hydrograph discharge calculated using the Nakayasu HSS method is the watershed area $(A)=1961.53 \mathrm{~km}$, length of main river $(\mathrm{L})=157.02 \mathrm{~km}$, time delay $(\operatorname{tg})=9.507$ hours, duration of rain $(\operatorname{Tr})=7,13$ hours, the time from the beginning of the flood to the peak of the flood hydrograph (tp) $=15.21$ hours, the time of discharge 0.3 times the peak flood discharge $(\mathrm{t} 0.3)=19.01$ hours and the peak flood discharge $(\mathrm{Qp})=23.109 \mathrm{~m} 3 / \mathrm{sec}$ then the total hydrograph discharge obtained by the Nakayasu method is equal to $=2040.26 \mathrm{~m} 3 / \mathrm{sec}$.
\end{abstract}

Keywords: Flood, Krueng Meureubo, HSS Nakayasu, Flood Hydrograph

\section{Introduction}

Flood is a familiar word for the people of Indonesia, floods that occur repeatedly every year as if it has become an annual agenda that will not be missed either in the city or in various remote areas. At the time of entering the rainy season, residents who live in low areas or who live in settlements near the river start to fret, this is caused by high rainfall which can cause rivers with low capacity unable to accommodate high discharge so that the river overflows and floods occur, events like this occur in the following years. Frequent flooding is also a result of a lack of public awareness of good upstream land use management. Land use that is not in accordance with its capabilities can result in decreased soil infiltration which causes surface runoff to increase.

Similar to other areas that are frequently affected by floods, Pasi Pinang Village, located in Meureubo Sub-District, West Aceh Regency, almost annually also experiences this disaster. Pasi Pinang Village is one of the villages prone to flooding because the area is located in a low place and located with the Krueng Meureubo River Basin, the flooding that occurred in this village was the result of the overflowing of the river which occurred almost every year.

Floods that occur due to the overflow of the Meureubo river have not only affected Pasi Pinang Village but also in the surrounding villages that are also close to the river, as a result many houses and rice fields have been flooded within a period of time which can take days. during rain with high intensity it still engulfs the area. In this matter, it is necessary to study the Analysis of Flood Discharge in the Krueng Meureubo Watershed using the Nakayasu method. 


\section{Methods}

\subsection{Design rainfall}

Rainfall is a major factor controlling the ongoing hydrological cycle in a watershed area (a key element that needs to be known to underlie understanding of soil moisture, groundwater infiltration processes, and flowrate). As it is known that the sustainability of ecological, geographic, and land use processes in a watershed is determined by the ongoing hydrological cycle, and thus, precipitation can be seen as a supporting factor as well as a limitation for water and land resource management efforts (Darmawan, 2013). Design rainfall is the largest annual rainfall with a certain probability or rain with a certain return period possibility.

\subsection{Frequency Analysis}

Frequency analysis is not to determine the amount of river flow at a time, but it is more appropriate to estimate whether the flow of the river will exceed or equal a certain value for example for the next 10 years, 20 years, and so on. In hydrology, the analysis is used to determine the amount of rain and design flood with a certain return period. (Mangangka, 2016). To predict rainfall, a plan is carried out by analyzed the frequency of rainfall data. There are several frequency analysis methods that can be used, namely:

Log Person type III method, if described on logarithmic opportunity paper will form a straight line equation, so that it can be expressed as a mathematical model with the equation as follows (Suripin, 2003):

$\mathrm{Y}=\mathrm{Y}+\mathrm{k} \cdot \mathrm{S}$

where:

$\mathrm{Y}=$ Logarithmic value and $\mathrm{X}$ or $\log \mathrm{X}$ with a certain return period

$\mathrm{Y}=$ Calculate average (preferably geometric mean $\mathrm{Y}$ )

$\mathrm{S}=$ standard deviation of the value of $\mathrm{Y}$

$\mathrm{k}=$ Characteristic distribution of type III log person opportunities

\subsection{Design Flood}

Design flood discharge is the maximum discharge in a river or natural channel with a predetermined return period. Design flood discharge is calculated based on the relationship between rain and flow. In this study the method used to calculate the flood discharge plan is using the Nakayasu Hydrograph method. Nakayasu (1950) in Kamiana (2010) has investigated hydrographs in Japan and provided a set of equations to form a unit hydrograph as follows:

1. Time lag (time lag, $\mathrm{tg}$ ), equals:

$\mathrm{t}_{\mathrm{g}}=0.4+0.058 \mathrm{~L} \rightarrow$ for $\mathrm{L}>15 \mathrm{~km}$

$\mathrm{t}_{\mathrm{g}}=0.21 \times \mathrm{L}^{0,7} \quad \rightarrow \quad$ for $\mathrm{L}<15 \mathrm{~km}$

2. The peak time and peak discharge of the synthesis unit hydrograph are formulated as follows:

$\mathrm{t}_{\mathrm{p}}=\mathrm{t}_{\mathrm{g}}+0.8 . \operatorname{Tr}$

3. The time when the discharge is equal to 0.3 times the peak discharge:

$\mathrm{t}_{0.3}=\alpha \times \mathrm{t}_{\mathrm{g}}$

4. The peak discharge of the synthesis unit hydrograph is formulated as follows:

$\mathrm{Qp}=\frac{1}{3.6} \times \mathrm{A} \times \mathrm{R} 0 \times \frac{1}{0.3 x t p+t 0.3}$.

Where:

Qp : Flood peak discharge (m3 / sec)

A : watershed area $(\mathrm{km} 2)$

$\mathrm{R} 0$ : rain depth unit ( $\mathrm{mm})$

$\mathrm{Tp}$ : time from the beginning of the flood to the peak of the flood hydrograph (hour)

t0.3 : time of discharge 0.3 times peak flood discharge (hour)

$\operatorname{tg}$ : delay time (hours)

Tr: duration of rain (hours $)=(0.5 \times \mathrm{tg})$ to $(1 \times \mathrm{tg})$

$\alpha$ : watershed characteristic coefficient, the value is between $1.5-3.0$

$\mathrm{L}$ : longest main river length $(\mathrm{km})$ 


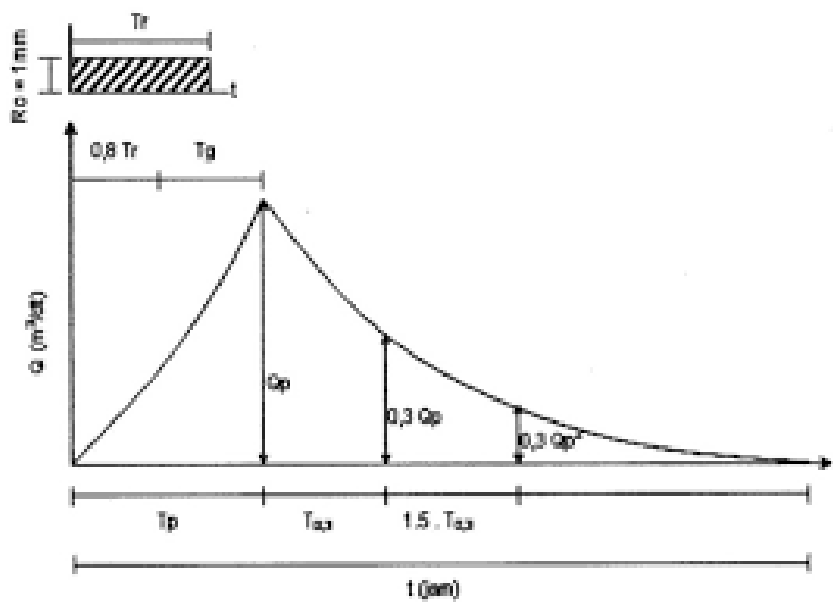

Fig. 1 HSS Nakayasu

\section{Result and Discussion}

\subsection{Frequency Analysis}

The Pearson Type III Log Distribution or Type III Extreme Distribution is used for the analysis of hydrological variables with minimum variance values such as the analysis of the frequency distribution of minimum flows (low flows). Pearson Log Type III distribution, has a coefficient of skewness (Coefficient of skewness) or CS $\neq 0$.

Table 1. Analysis of rainfall log distribution type Pearson type III

\begin{tabular}{|c|c|c|c|c|c|c|c|}
\hline \multicolumn{8}{|c|}{ Log person III method } \\
\hline No & Year & $\mathbf{x}$ & $\log X$ & $\begin{array}{c}(\log x- \\
\text { Log } \\
\text { Xbar })\end{array}$ & $\begin{array}{c}(\log x- \\
\log \\
{\text { Xbar })^{\wedge} 2}^{2}\end{array}$ & $\begin{array}{c}(\log x- \\
\log \\
\text { Xbar })^{\wedge} 3\end{array}$ & $\begin{array}{c}\log x- \\
\log \\
{\text { Xbar })^{\wedge} 4}\end{array}$ \\
\hline 1 & 2005 & 106 & 2,0253 & $-0,0079$ & 0,0001 & 0,0000 & 0,0000 \\
\hline 2 & 2006 & 107 & 2,0294 & $-0,0038$ & 0,0000 & 0,0000 & 0,0000 \\
\hline 3 & 2007 & 135 & 2,1303 & 0,0971 & 0,0094 & 0,0009 & 0,0001 \\
\hline 4 & 2008 & 100 & 2,0000 & $-0,0332$ & 0,0011 & 0,0000 & 0,0000 \\
\hline 5 & 2009 & 100 & 2,0000 & $-0,0332$ & 0,0011 & 0,0000 & 0,0000 \\
\hline 6 & 2010 & 101 & 2,0022 & $-0,0310$ & 0,0010 & 0,0000 & 0,0000 \\
\hline 7 & 2011 & 105 & 2,0212 & $-0,0120$ & 0,0001 & 0,0000 & 0,0000 \\
\hline 8 & 2012 & 106,5 & 2,0273 & $-0,0059$ & 0,0000 & 0,0000 & 0,0000 \\
\hline 9 & 2013 & 85,5 & 1,9320 & $-0,1012$ & 0,0102 & $-0,0010$ & 0,0001 \\
\hline 10 & 2014 & 146 & 2,1644 & 0,1311 & 0,0172 & 0,0023 & 0,0003 \\
\hline Total & & 1092 & 20,3320 & 0,0000 & 0,0403 & 0,0020 & 0,0005 \\
\hline Avarage & & 109,15 & 2,0332 & 0,0000 & 0,0040 & 0,0002 & 0,0000 \\
\hline $\mathrm{S} \log$ & 0,0669 & & & & & & \\
\hline Cs log & 0,9402 & & & & & & \\
\hline $\mathrm{Cv} \log$ & 0,0006 & & & & & & \\
\hline $\mathrm{Ck} \log$ & 0,2286 & & & & & & \\
\hline
\end{tabular}

According to anlayzed that showed at Table 1 Pearson III log distribution calculations. From the results of the calculations that have been made, the results of $\mathrm{Cs}=0.9402$ and $\mathrm{Ck}=0.2286$. After doing this calculation, then calculate the rainfall log III distribution plan.

Table 2. Calculation of rainfall log distribution type Pearson type III

\begin{tabular}{|c|c|c|c|c|c|}
\hline $\mathrm{T}$ & $\mathrm{P}_{\mathrm{T}}$ & $G$ & $\mathrm{Gs}_{\mathrm{s}}$ & $\mathrm{I} \cap 0 \mathrm{RT}$ & $\mathrm{RT}$ \\
\hline (tahun) & $(\%)$ & 4 & 0.5 & Log 11 & $(\mathrm{~mm})$ \\
\hline$(1)$ & $(2)$ & (3) & (4) & (5) & (6) \\
\hline 2 & 5 & $-0,154$ & $-0,010$ & 2,023 & 105,407 \\
\hline 5 & 2 & 0,765 & 0,051 & 2,084 & 121,443 \\
\hline 10 & 1 & 1,339 & 0,090 & 2,123 & 132,678 \\
\hline
\end{tabular}


Based on Table 2. can be seen the amount of rain discharges in the return period (T). The table also explains that the highest rainfall occurs in the 10 years return period, reaching $132,678 \mathrm{~mm} /$ hour.

\subsection{Analysis of the HSS Nakayasu Method}

Before calculating peak discharges using the Nakayasu method, the longest river length, watershed area and rain depth unit must be known. In this study it is known that the longest river length of the Krueng Meureubo watershed is 157.02, the area of the Krueng Meureubo watershed is $1961.53 \mathrm{~km} 2$ and the unit discharge into the rain is $472.15 \mathrm{~mm}$, for more details, see Table 3 .

Table 3. Krueng meureubo watershed parameters

\begin{tabular}{lrl}
\hline \multicolumn{1}{c}{ Parameter Nakayasu } & Hasil & \\
\hline Luas DAS & 1961.53 & $\mathrm{~km}^{2}$ \\
Panjang Sungai Utama (L) & 157.02 & $\mathrm{Km}$ \\
$\mathrm{tg}_{\mathrm{g}}$ & 9.50716 & $\mathrm{jam}$ \\
$\mathrm{Tr}$ & 7.13 & $\mathrm{jam}$ \\
$\mathrm{t}_{\mathrm{p}}$ & 15.21 & $\mathrm{jam}$ \\
$\mathrm{t}_{0,3}$ & 19.01432 & $\mathrm{jam}$ \\
$\mathrm{Qp}$ & 23.109 & $\mathrm{~m}^{3} / \mathrm{det}$ \\
\hline
\end{tabular}

From Table 3. it can be seen that the humidity time $(\operatorname{tg})$ is 9.507 hours, $\operatorname{Tr}=7.13, \mathrm{Tp}=15.21, \mathrm{t} 0.3=19.014$ and $\mathrm{Qp}=23.109$.

Table 4. Nakayasu HSS Hydrograph Method

\begin{tabular}{|c|c|c|c|c|c|c|}
\hline \multirow[t]{2}{*}{ No. } & \multirow{2}{*}{$\begin{array}{c}\mathrm{t} \\
\text { (hour) }\end{array}$} & \multirow{2}{*}{$\begin{array}{c}\text { HSS } \\
\left(\mathrm{m}^{3} / \operatorname{det} / \mathrm{mm}\right)\end{array}$} & \multicolumn{3}{|c|}{ Hidrograf (m3/dsec) } & \multirow{2}{*}{$\frac{\text { Total Hidrograf }}{\left(\mathrm{m}^{3} / \mathrm{det}\right)}$} \\
\hline & & & $25 \mathrm{~mm}$ & $50 \mathrm{~mm}$ & $15 \mathrm{~mm}$ & \\
\hline$(1)$ & (2) & (3) & (4) & $(5)$ & $(6)$ & (7) \\
\hline 1 & 0 & 0,00 & 0,00 & & & 0,00 \\
\hline 2 & 1 & 0,03 & 0,84 & 0,00 & & 0,84 \\
\hline 3 & 2 & 0,18 & 4,44 & 1,68 & 0,00 & 6,12 \\
\hline 4 & 3 & 0,47 & 11,74 & 8,87 & 0,50 & 21,11 \\
\hline 5 & 4 & 0,94 & 23,41 & 23,48 & 2,66 & 49,55 \\
\hline 6 & 5 & 1,60 & 40,00 & 46,83 & 7,04 & 93,87 \\
\hline 7 & 6 & 2,48 & 61,96 & 80,00 & 14,05 & 156,00 \\
\hline 8 & 7 & 3,59 & 89,69 & 123,91 & 24,00 & 237,60 \\
\hline 9 & 8 & 4,94 & 123,58 & 179,38 & 37,17 & 340,13 \\
\hline 10 & 9 & 6,56 & 163,95 & 247,15 & 53,82 & 464,91 \\
\hline 11 & 10 & 8,44 & 211,12 & 327,89 & 74,15 & 613,15 \\
\hline 12 & 11 & 10,62 & 265,38 & 422,23 & 98,37 & 785,98 \\
\hline 13 & 12 & 13,08 & 327,01 & 530,75 & 126,67 & 984,43 \\
\hline 14 & 13 & 15,85 & 396,26 & 654,01 & 159,23 & 1209,50 \\
\hline 15 & 14 & 18,94 & 473,40 & 792,53 & 196,20 & 1462,13 \\
\hline 16 & 15 & 22,35 & 558,65 & 946,80 & 237,76 & 1743,21 \\
\hline 17 & 15,21 & 23,11 & 577,74 & 1117,30 & 284,04 & 1979,07 \\
\hline 18 & 16 & 21,98 & 549,60 & 1155,47 & 335,19 & 2040,26 \\
\hline 19 & 17 & 20,64 & 515,88 & 1099,20 & 346,64 & 1961,72 \\
\hline 20 & 18 & 19,37 & 484,23 & 1031,75 & 329,76 & 1845,74 \\
\hline 21 & 19 & 18,18 & 454,51 & 968,45 & 309,53 & 1732,49 \\
\hline 22 & 20 & 17,07 & 426,63 & 909,03 & 290,54 & 1626,19 \\
\hline 23 & 21 & 16,02 & 400,45 & 853,25 & 272,71 & 1526,42 \\
\hline 24 & 22 & 15,04 & 375,88 & 800,90 & 255,98 & 1432,76 \\
\hline 25 & 23 & 14,11 & 352,82 & 751,76 & 240,27 & 1344,85 \\
\hline 26 & 24 & 13,25 & 331,17 & 705,64 & 225,53 & 1262,34 \\
\hline
\end{tabular}


the calculation continues until the duration of 256 hours, so that at 256 hours can be:

\begin{tabular}{lllllll}
\hline 256 & 254 & 0,00 & 0,12 & 0,25 & 0,08 & 0,45 \\
\hline 255 & & & 0,24 & 0,08 & 0,32 \\
\hline 256 & & & 0,07 & 0,07 \\
\hline
\end{tabular}

From the table above we can see the magnitude of flood discharge calculated by the Nakayasu HSS method. For more details, the peak discharge of the Nakayasu Hydrograph can be seen in Figure 2.

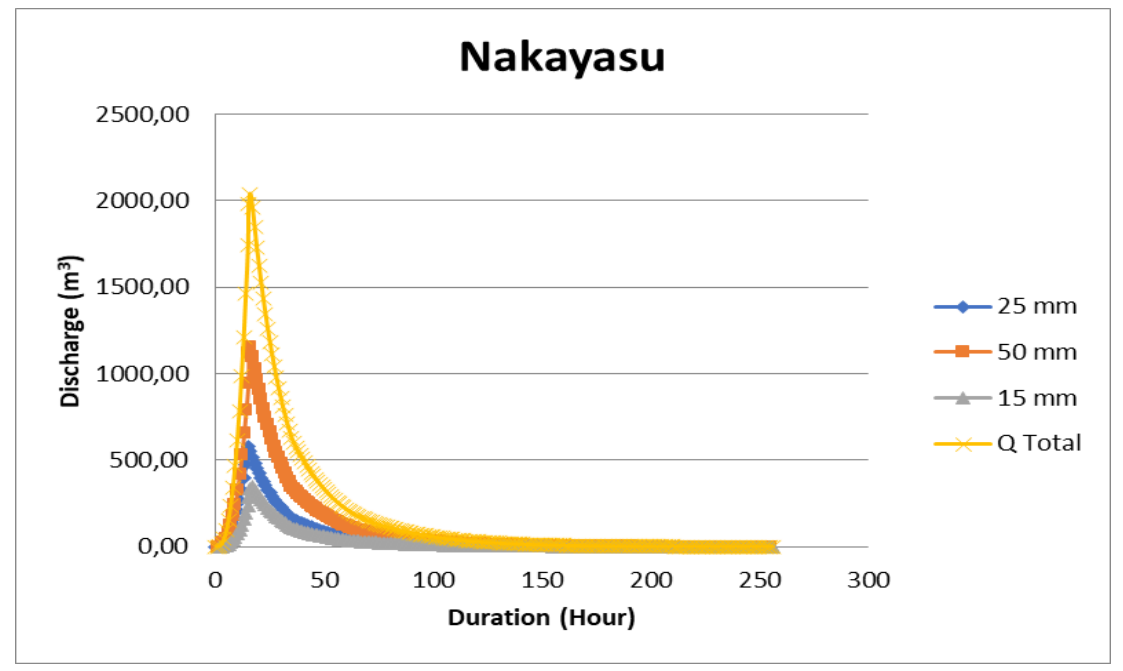

Fig 2. Nakayasu Hydrograph synthetic

From Figure 2, it can be seen that the peak discharge that occurred in the Krueng Meureubo watershed in Pasi Pinang Village, Meureubo District, West Aceh Regency, which was calculated using the Nakayasu HSS method was $2040.26 \mathrm{~m} 3$ / sec.

\section{Conclusion}

1. From the analysis of rainfall data frequency with several distributions, namely gumbel, normal, normal log and log person III, it is obtained that the distribution results suitable for use are log person III distribution with the terms Cs $\neq 0$ and the calculation results $\mathrm{Cs}=0.7884$ for this distribution log person III is eligible.

2. Total hydrograph discharge calculated using the Nakayasu HSS method is with an area of watershed $(\mathrm{A})=1961.53 \mathrm{~km}$, length of main river $(\mathrm{L})=157.02 \mathrm{~km}$, delay time $(\operatorname{tg})=9.507$ hours, duration of rain $(\operatorname{Tr})=7.13$ hours, the time from the beginning of the flood to the peak of the flood hydrograph $(\mathrm{tp})=15.21$ hours, the time of discharge 0.3 times the peak flood discharge $(\mathrm{t} 0.3)=19.01$ hours and the peak flood discharge $(\mathrm{Qp})=23,109 \mathrm{~m} 3 / \mathrm{sec}$, the total hydrograph discharge obtained by the Nakayasu method is equal to $=2040.26 \mathrm{~m} 3 / \mathrm{sec}$.

\section{Acknowledgement}

First of all the authors thanked ALLAH SWT who has given blessings to the author so that he can complete this research, then the authors also said to the research team who were very helpful during this research, from collection to the end. to the Dean of the Faculty of Engineering Dr. Ir. M. Isya, MT, the authors would like to thank you for your support so that we can carry out this research, we thank the rector of Teuku Umar University Prof. Dr. Jasman j Ma'ruf, SE, MBA for the Opportunity, Last but not least to all those who have helped with this research process that cannot be mentioned individually.

\section{References}

[1] Darmawan, 2013. Analisis Hidrograf Sungai Dengan Menggunakan Hss Di Daerah Aliran Sungai Saddang Kabupaten Pinrang, Jurusan Teknik Sipil, Fakultas Teknik, Universitas Hasanuddin, Makassar.

[2] Kamiana, M.I., 2010. Teknik Perhitungan Debit Rencana Bangunan Air._Penerbit Graha Ilmu, Palangka Raya.

[3] Mangangka, I., 2016. Analisa Debit Banjir Sungai Ranoyapo Di Desa Lindangan, Kec.Tompaso Baru, Kab. Minahasa Selatan, Program Study Teknik Sipil, Fakultas Teknik, Universitas Sam Ratulangi, Manado.

[4] Suripin., 2003. Pelestarian Sumber Daya Tanah dan Air ${ }_{2}$ ANDI, Yogyakarta. 